\title{
Association between common mental disorders and quality of life in older adults
}

\author{
Associação entre transtorno mental comum e qualidade de vida de pessoas idosas \\ Asociación entre el trastorno mental común y la calidad de vida de los adultos mayores
}

How to cite this article:

Souza Júnior EV, Cruz DP, Siqueira LR, Rosa RS, Silva CS, Sawada NO. Association between common mental disorders and quality of life in older adults. Rev Esc Enferm USP. 2021;55:e20210057. DOI: https://doi.org/10.1590/1980-220X-REEUSP-2021-0057

\author{
Edison Vitório de Souza Júnior ${ }^{1}$ \\ Diego Pires Cruz ${ }^{2}$ \\ Lais Reis Siqueira ${ }^{3}$ \\ Randson Souza Rosa ${ }^{4}$ \\ Cristiane dos Santos Silva ${ }^{5}$ \\ Namie Okino Sawada ${ }^{3}$ \\ ${ }^{1}$ Universidade de São Paulo, Escola de \\ Enfermagem de Ribeirão Preto, Programa \\ de Pós-Graduação em Enfermagem \\ Fundamental, Ribeirão Preto, SP, Brazil. \\ ${ }^{2}$ Universidade Estadual do Sudoeste da \\ Bahia, Programa de Pós-Graduação em \\ Enfermagem e Saúde, Jequié, BA, Brazil. \\ ${ }^{3}$ Universidade Federal de Alfenas, Programa \\ de Pós-Graduação em Enfermagem, \\ Alfenas, MG, Brazil. \\ ${ }^{4}$ Universidade Federal de Minas Gerais, \\ Faculdade de Medicina, Departamento \\ de Medicina Preventiva e Social, \\ Belo Horizonte, MG, Brazil. \\ ${ }^{5}$ Universidade Norte do Paraná, \\ Jequié, BA, Brazil.
}

\begin{abstract}
Objective: to analyze the association between common mental disorder and quality of life in older adults. Method: cross-sectional study developed with a total of 721 Brazilian older adults between July and October 2020. Participants completed three instruments to assess bio sociodemographic, mental health and quality of life data. Data were analyzed using Mann-Whitney U, Kruskal-Wallis H, Chi-square, Pearson correlation and multivariate linear regression tests, considering a 95\% confidence interval $(p<0.05)$ for all analyses. Results: among the four components that assess common mental disorder, only three remained associated with negative coefficients with the participants' general quality of life: depressive-anxious $\operatorname{mood}(\beta=-2.050$; [CI95\% $=-2.962--1.137$; $\mathrm{p}<0.001)$; decrease in vital energy $(\beta=-1.460 ;[$ CI95\% $=-2.197--0.723] ; \mathrm{p}<0.001)$ and depressive thoughts $(\beta=-4.124 ;$ [CI95\% $=-5.211--3.038] ; p<0.001)$. Conclusion: most components that assess common mental disorders are negatively associated with quality of life, that is, the increase in these disorders resulted in a reduction in the quality of life of older adults.
\end{abstract}

\section{DESCRIPTORS}

Public Health; Health of the Elderly; Mental Health; Mental Disorders; Ageism; Quality of life. 


\section{INTRODUCTION}

Epidemiological projections indicate that the number of older adults will increase significantly worldwide in the coming decades. The number of people aged 60 years old and over will increase from 901 million, estimated in 2015, to 2.1 billion in 2050 and 3.2 billion in $2100^{(1)}$.

Reaching old age in the old days was a limited privilege, but nowadays it has become common even in developing countries. However, the aging process tends to bring organic changes, such as the progressive decline of functions, culminating in the greater vulnerability of older adults to physical and mental pathologies, and this reality is considered a major challenge for the current century ${ }^{(2)}$.

Existing data on the mental health of older adults attest that this is a problem of great impact for this group and that, often, suffering or psychological illness tends to be the causal or intensifier factor of physical illnesses. Thus, the changes suffered in the epidemiological profile are accompanied by some disorders, such as common mental disorders $(\mathrm{CMD})^{(3)}$.

CMD can be defined as a set of somatic, anxious and depressive manifestations ${ }^{(4)}$, such as memory and concentration difficulties, irritability, insomnia, fatigue and feelings of uselessness $^{(4)}$, affecting cognitive, physical, emotional functions and behavioral aspects of the individuals ${ }^{(5)}$. Although they are not as serious as psychotic disorders, CMD represent an important public health problem due to their high prevalence and their deleterious effects on personal, family and work well-being; increased use of health services ${ }^{(3,5)}$ and compromised Quality of Life (QoL) $)^{(3)}$.

Non-psychotic mental disorders or CMD are highly prevalent in the world population. International studies that used the Self-report Questionnaire (SRQ-20) instrument for CMD screening, similarly to this study, are scarce, whose evidence found demonstrates a prevalence of $32.4 \%$ in Ethiopia ${ }^{(6)}$. In Brazil, studies have identified a prevalence of CMD among older adults ranging from $28.2 \%$ in Rio Grande do Norte ${ }^{(7)}$, 29.7\% in Sao Paulo ${ }^{(8)}$ and $32.1 \%$ to $55.8 \%$ in Bahia ${ }^{(3,9)}$.

From this perspective, there is the certainty that it is not enough to just extend the years of life, it is important to add greater quality to the additional years ${ }^{(2)}$ and to the mental health of older adults, which makes this study relevant to the current scenario, especially in the context of the pandemic caused by COVID-19. Thus, previous investigations carried out in pandemic situations have shown that, during quarantine, some CMD can be triggered, such as anxiety ${ }^{(10)}$ and depression $^{(11)}$ disorders. Furthermore, older adults population is considered a vulnerable group and at high risk for fatal outcomes in pandemic situations, mainly due to the higher prevalence of comorbidities in this age group ${ }^{(12)}$.

A Brazilian investigation ${ }^{(8)}$ carried out in the State of Sao Paulo with a total of 1,520 older adults showed that CMD were associated with lower income, unemployment, sedentary lifestyle, worse health assessment and a higher number of chronic pathologies. Another study ${ }^{(3)}$ carried out in the State of Bahia with 310 older adults revealed that CMD were significantly associated with the presence of asthma/bronchitis, hypercholesterolemia, rheumatism, back pain, low income, more time people spend sitting per week, among other investigated variables that can generate unsatisfactory repercussions on the QoL of older adults.

Given the above, the development of this study is justified, in order to provide current data on the relationship between CMD and QoL in older adults and enable the implementation of strategic actions in primary care for the reduction, control and prevention of stressors that affect these variables in this audience. Thus, the aim of this study was to analyze the association between common mental disorders and the quality of life of older adults.

\section{METHOD}

\section{Design of Study}

This is a cross-sectional study developed in accordance with the recommendations of the Strengthening the Reporting of Observational Studies in Epidemiology (STROBE) tool.

\section{LOCAL}

The study scenario was the Facebook Social Network. Thus, there was no face-to-face meetings with the participants and the participation of those involved in the research was entirely online, through internet access in their home.

\section{Sample Definition}

At first, the required sample was defined considering an infinite population, $5 \%$ sampling error and $95 \%$ confidence interval, which resulted in a minimum sample of 385 participants. However, considering the possibility of incomplete answers to the questionnaire, it was decided to add more than $80 \%(n=336)$ to the calculation, with a final sample of 721 participants who were selected by the non-probabilistic consecutive sampling technique.

The following inclusion criteria were adopted: living in Brazilian territory and in a community; being 60 years old or older; of both gender (male, female or others); having a valid email address; being married, in a stable relationship or with a regular partner; having access to the internet and an active Facebook account. The option "others" included in the gender variable refers to non-binary participants or those who do not identify with any social classifications or gender. Exclusion criteria were older adults living in long-term care facilities or something similar to it. It is noteworthy that there was no application of an instrument to assess the cognitive status of the participants, as they understand that the skills needed for active interaction in a social network through electronic equipment such as smartphones, tablets, laptops, among others, already attest to preserved cognition.

\section{Data Collection}

Data collection took place between July and October, in 2020. An online page was created on Facebook in order to promote the development of scientific research and disseminate information about sexuality, health and QoL of older 
adults. On this page, the authors published a thematic invitation that contained the name of the research, the responsible researchers, the link institution, the inclusion criteria and contact details (phone and email) of those responsible for the study. In addition, the invitation was accompanied by a hyperlink that directed participants to the study questionnaire, which was organized on the Google Forms platform and structured with three instruments for bio sociodemographic, mental health and QoL assessment.

In the initial section, it was mandatory to include a valid email address, so that the participant would only be able to come up with the answers if this field was filled out. The inclusion of this email served as a data control strategy, in which the researchers could track and correct a possible multiplicity of responses by the same participant.

The bio sociodemographic instrument was developed by the researchers and incorporated questions that could trace the profile of the participants, such as gender (male, female or others), age group (only considering older adults $\geq 60$ years old), marital status (married, in stable union or with a regular partner), time living with the spouse (in years), Brazilian region where they live (North, Northeast, Midwest, Southeast and South), education (no education, primary education, elementary school, middle school, high school and higher education), ethnicity (white, yellow, black, brown, indigenous), sexual orientation (heterosexual, homosexual, bisexual, others), religious belief (no religion, Catholic, Protestant, Spiritist, beliefs of African origins, others) and if they live with their children (yes, no and do not have children).

The instrument used to collect data on CMD was the SRQ-20, adapted and validated for the Brazilian population $^{(13)}$. It consists of a total of 20 questions, whose answer possibilities are binary (yes/no) and structured in four domains: Depressive-Anxious Mood, Somatic Symptoms, Decrease in Vital Energy and Depressive Thoughts. The final score varies between 0 and 20 points and the cutoff point adopted in this study was $\geq 5$ positive responses for both genders, which will indicate the presence of CMD, according to previous studies conducted with the older adults population $^{(3,8)}$. Nevertheless, the SRQ-20 showed excellent reliability in this study, evidencing a Cronbach's alpha of 0.847 .

The QoL instrument used was the World Health Organization Quality of Life-Old (WHOQOL-Old), standardized and validated for the Brazilian older adults population $^{(14)}$. It consists of 24 items and six evaluation facets: sensory skills; autonomy; past, present and future activities; social participation; death and dying; and intimacy. It presents five possibilities for answers on a Likert scale, whose scores range between 1 and 5 points and the final scores range between 24 and 100 points. There is no cutoff point for this instrument. Its interpretation is carried out in the sense that the higher/lower the scores, respectively, the better/worse will be the individual's QoL ${ }^{(14)}$. Before performing the WHOQOL-Old analyses, the items must be recoded (old_01; old_02; old_06; old_7; old_8; old_9 and old_10) with the following rule regarding the answers given: $(1=5$;
$2=4 ; 3=3 ; 4=2$ and $5=1$ ). Finally, this instrument also showed excellent reliability using a 0.891 Cronbach's alpha.

The authors used the post boosting strategy to increase the engagement of profiles interested in the topic, in addition to expanding the dissemination of the questionnaire throughout the Brazilian territory, according to the inclusion criteria that were inserted in a specific field before the boost. The authors used this feature monthly through payment for the service to Facebook until reaching the intended sample. Thus, we managed to have the questionnaire widely disseminated throughout Brazil.

\section{Data Analysis and Treatment}

For data analysis, we used the IBM SPSS ${ }^{\circledR}$ statistical software, version 25. Initially, data distribution was analyzed using the Kolmogorov Smirnov test, by which nonnormality was found $(\mathrm{p}<0.05)$. Due to this characteristic, non-parametric statistics were adopted for the analysis of quantitative data with the Mann-Whitney $U$ test and the Kruskal-Wallis $\mathrm{H}$ test, applying Bonferroni`s Post-hoc test when necessary. These data were presented as mean ranks, median (Md) and interquartile range (IR). Categorical variables were analyzed using the chi-square test $\left(\chi^{2}\right)$ and presented using absolute and relative frequencies.

To verify the relationships between the independent (CMD) and the dependent (QoL) variable, Pearson's correlation analysis ( $r$ ) was performed, considering the four domains of the SRQ-20 and the six facets of QoL. Afterwards, the variables were included in a multivariate linear regression model, considering each of the facets of QoL. The model's adequacy was attested by the Durbin Watson test and the results were presented through the Beta coefficients $(\beta)$ and their respective confidence intervals. It is noteworthy that all analyzes were performed considering a confidence interval of $95 \%(p<0.05)$.

\section{Ethical Aspects}

This study was submitted to the Research Ethics Committee of the Nursing School in Ribeirão Preto, of the Universidade de São Paulo, and was approved in 2020, under the number 4,319,644, in accordance with Resolution 466/2012 of the National Health Council. In addition, the participants read and agreed with the Informed Consent Form, with a duplicate being sent to their emails informed in the initial stage of filling out the survey questionnaire.

\section{RESULTS}

In this study, a prevalence of CMD of $30.8 \%$ was observed, affecting a total of 222 participants. When comparing the bio sociodemographic characteristics with the suspicion of CMD, only the gender variable showed a statistically significant association, as shown in Table 1.

When comparing the bio sociodemographic variables with $\mathrm{QLL}$, it is noted that women $(\mathrm{p}<0.001)$ and participants in a stable relationship $(p=0.005)$ showed higher scores in the sensory abilities facet, as shown in Table 2. Furthermore, participants with higher education $(p=0.002)$, 
Table 1 - Comparison of bio sociodemographic characteristics with suspected CMD - Ribeirão Preto, SP, Brazil, 2020.

\begin{tabular}{|c|c|c|c|c|c|c|}
\hline \multirow{3}{*}{ Variables } & \multicolumn{4}{|c|}{ CMD } & \multirow{3}{*}{$\chi^{2}$} & \multirow{3}{*}{$p$ value } \\
\hline & \multicolumn{2}{|c|}{$\begin{array}{c}\text { No } \\
\text { suspicion }\end{array}$} & \multicolumn{2}{|c|}{ Suspicion } & & \\
\hline & $\mathbf{n}$ & $\%$ & $\mathbf{n}$ & $\%$ & & \\
\hline \multicolumn{7}{|l|}{ Gender } \\
\hline Male & 321 & 74.8 & 108 & 25.2 & \multirow{3}{*}{15.723} & \multirow{3}{*}{$<0.001 *$} \\
\hline Female & 176 & 60.9 & 113 & 39.1 & & \\
\hline Others & 2 & 66.7 & 1 & 33.3 & & \\
\hline \multicolumn{7}{|l|}{ Marital status } \\
\hline Married & 318 & 68.1 & 149 & 31.9 & \multirow{3}{*}{1.233} & \multirow{3}{*}{0.540} \\
\hline Stable union & 88 & 73.3 & 32 & 26.7 & & \\
\hline Regular partner & 93 & 69.4 & 41 & 30.6 & & \\
\hline \multicolumn{7}{|l|}{ Religion } \\
\hline Catholic & 268 & 68.2 & 125 & 31.8 & \multirow{6}{*}{5.160} & \multirow{6}{*}{0.397} \\
\hline Protestant & 66 & 67.3 & 32 & 32.7 & & \\
\hline Spiritist & 62 & 74.7 & 21 & 25.3 & & \\
\hline African origins & 7 & 50.0 & 7 & 50.0 & & \\
\hline Others & 39 & 68.4 & 18 & 31.6 & & \\
\hline No religion & 57 & 75.0 & 19 & 25.0 & & \\
\hline \multicolumn{7}{|c|}{ Living with their children } \\
\hline Yes & 130 & 65.7 & 68 & 34.3 & \multirow{3}{*}{1.622} & \multirow{3}{*}{0.444} \\
\hline No & 342 & 70.5 & 143 & 29.5 & & \\
\hline Do not have children & 27 & 71.1 & 11 & 28.9 & & \\
\hline \multicolumn{7}{|l|}{ Ethnicity } \\
\hline White & 343 & 68.9 & 155 & 31.1 & \multirow{6}{*}{8.390} & \multirow{6}{*}{0.136} \\
\hline Yellow & 5 & 38.5 & 8 & 61.5 & & \\
\hline Black & 27 & 77.1 & 8 & 22.9 & & \\
\hline Brown & 117 & 71.8 & 46 & 28.2 & & \\
\hline Indigenous & 4 & 66.7 & 2 & 33.3 & & \\
\hline Do not know & 3 & 50.0 & 3 & 50.0 & & \\
\hline \multicolumn{7}{|l|}{ Brazilian region } \\
\hline North & 24 & 72.7 & 9 & 27.3 & \multirow{5}{*}{0.547} & \multirow{5}{*}{0.969} \\
\hline Northeast & 86 & 67.7 & 41 & 32.3 & & \\
\hline Midwest & 41 & 71.9 & 16 & 28.1 & & \\
\hline Southeast & 223 & 69.3 & 99 & 30.7 & & \\
\hline South & 125 & 68.7 & 57 & 31.3 & & \\
\hline \multicolumn{7}{|l|}{ Education } \\
\hline Primary education & 37 & 59.7 & 25 & 40.3 & & \\
\hline Elementary school & 42 & 79.2 & 11 & 20.8 & & \\
\hline Middle school & 30 & 76.9 & 9 & 23.1 & 9.157 & 0.103 \\
\hline High school & 172 & 67.2 & 84 & 32.8 & & \\
\hline Higher education & 218 & 70.3 & 92 & 29.7 & & \\
\hline No education & 0 & 0.0 & 1 & 100 & & \\
\hline
\end{tabular}

*Statistical significance for the chi-square test $(p<0.05)$.

belonging to the Spiritism religion $(\mathrm{p}=0.015)$ and heterosexuals $(p=0.002)$ had higher scores in the autonomy facet, with detection of statistically significant differences through Bonferroni's post-hoc.

According to Table 3, it is observed that, regardless of the suspicion of CMD, the participants had better QoL in the sensory abilities facets $(\mathrm{p}<0.001)$. Nevertheless, the comparison between groups using the Mann-Whitney test showed that older adults with no suspicion of CMD have better QoL in all facets when compared with those with no suspicion $(\mathrm{p}<0.001)$.

Table 4 demonstrates that the components of the SRQ-20 that assess the CMD showed negative and statistically significant correlations with all facets of $\mathrm{QLL}(\mathrm{p}<0.001)$.

In the multivariate linear regression analysis for each facet of QoL, different components of the CMR were associated, however, all with a negative relationship, that is, the increase in the SRQ-20 scale implies a reduction of different magnitudes in the facets of QoL. In addition, it is noted that the depressive-anxious mood was the component that was most associated with almost all facets of QoL, with the exception of autonomy, as shown in Table 5.

\section{DISCUSSION}

In this study, it was observed a prevalence of CMD of $30.8 \%$ among older adults who participated in the study, configuring itself as a serious public health problem ${ }^{(9)}$. These results corroborate similar studies that also used the SRQ-20 as a screening tool for CMD, which showed a prevalence ranging from $27.7 \%$ in the state of Sao Paulo ${ }^{(8)}, 44.6 \%$ in Minas Gerais ${ }^{(15)}$ and $55.8 \%$ in Bahia ${ }^{(3)}$.

A Brazilian investigation ${ }^{(15)}$ carried out with a total of 419 older adults identified that the prevalence of CMD found among the interviewees was associated with the sociodemographic profile and, especially, with worse subjective health conditions, in addition to a higher prevalence among older adults who reported dissatisfaction with life. In this context, the authors reported the need to implement care policies for older adults that consider aspects related to mental health in order to promote aging with $\mathrm{QoL}$ and health ${ }^{(15)}$.

Furthermore, the higher prevalence of CMD in women observed in this study was statistically significant, corroborating other similar investigations $s^{(3,8)}$ and even those carried out with different instruments and/or cutoff points ${ }^{(9,15)}$. The literature indicates that women are the most vulnerable to the development of mental disorders due to several factors, such as endocrine changes that occur in the premenstrual period, postpartum and menopause, specificities in the brain field common to women, in addition to the gender inequalities that affect the burden of domestic tasks and the rates of violence, which are considered a factor of greater impact associated with $\mathrm{CMD}^{(16)}$.

In this study, attention is drawn to the fact that older adults with higher education, belonging to the Spiritism religion and heterosexuals, have higher scores in the autonomy facet, corroborating a study ${ }^{(17)}$ carried out with a total of 1,252 Mexican older adults, which observed that, among other factors, low autonomy is associated with low education and low spirituality.

Autonomy concerns the ability or freedom of older adults to make decisions and experience their old age autonomously and independently ${ }^{(18)}$, deciding aspects that they believe are best for them and that are in accordance with their social, cultural and religious values ${ }^{(19-20)}$. Therefore It is an essential concept because it involves issues related to human dignity, regardless of health conditions ${ }^{(17)}$, that is, the exercise of 
Table 2 - Comparison of bio sociodemographic characteristics with the facets of QoL - Ribeirão Preto, SP, Brazil, 2020.

\begin{tabular}{|c|c|c|c|c|c|c|c|}
\hline & \multicolumn{7}{|c|}{ WHOQOL-OId FACETS } \\
\hline & SS & AUT & PPFA & SP & DD & INT & GQoL \\
\hline & \multicolumn{7}{|c|}{ Mean ranks } \\
\hline \multicolumn{8}{|l|}{ Gender } \\
\hline Male & $335.73^{+}$ & 363.49 & 361.47 & 361.07 & 370.91 & 363.20 & 359.62 \\
\hline Female & $398.54^{+}$ & 359.58 & 361.88 & 362.18 & 345.80 & 358.19 & 363.47 \\
\hline Others & 358.17 & 141.67 & 209.00 & 237.00 & 408.00 & 317.50 & 321.33 \\
\hline $\mathrm{p}$ value & $<0.001 *$ & 0.178 & 0.443 & 0.579 & 0.261 & 0.886 & 0.919 \\
\hline \multicolumn{8}{|l|}{ Marital status } \\
\hline Married & $343.09^{+}$ & 346.56 & 357.82 & 352.56 & 360.95 & 344.08 & 346.35 \\
\hline Stable union & $404.04^{+}$ & 388.70 & 366.51 & 380.36 & 371.00 & 393.83 & 393.40 \\
\hline Regular partner & 384.86 & 386.51 & 367.16 & 373.07 & 352.21 & 390.57 & 383.05 \\
\hline $\mathrm{p}$ value & $0.005^{*}$ & $0.039 *$ & 0.854 & 0.318 & 0.771 & $0.010^{*}$ & $0.035^{*}$ \\
\hline \multicolumn{8}{|l|}{ Education } \\
\hline Primary education & 283.94 & $279.28^{+}$ & 356.78 & 373.72 & 403.83 & 352.48 & 331.90 \\
\hline Elementary school & 352.75 & 332.06 & 341.52 & 348.55 & 360.60 & 373.86 & 342.41 \\
\hline Middle school & 385.53 & 382.33 & 377.51 & 362.35 & 350.47 & 356.97 & 362.08 \\
\hline High school & 364.18 & 351.52 & 362.44 & 363.38 & 347.71 & 365.27 & 357.91 \\
\hline Higher education & 372.01 & $388.29^{+}$ & 362.99 & 359.51 & 364.43 & 357.92 & 373.25 \\
\hline No education & 391.50 & 98.00 & 28.00 & 34.00 & 474.50 & 227.00 & 103.00 \\
\hline$p$ value & 0.070 & $0.002^{*}$ & 0.642 & 0.702 & 0.524 & 0.966 & 0.507 \\
\hline \multicolumn{8}{|l|}{ Religion } \\
\hline Catholic & 360.35 & 356.14 & 352.33 & 353.62 & 351.70 & $343.45^{+}$ & $348.51^{+}$ \\
\hline Protestant & 323.24 & $316.89^{+}$ & 336.33 & 372.20 & 391.15 & $345.36^{\ddagger}$ & $345.46^{\ddagger}$ \\
\hline Spiritists & 389.44 & $427.55^{+}$ & 424.80 & 420.55 & 372.93 & $436.86^{t, \neq}$ & $438.02^{+, \neq}$ \\
\hline African origins & 295.56 & 388.29 & 311.75 & 296.75 & 297.57 & 371.71 & 302.61 \\
\hline Others & 342.29 & 347.51 & 398.02 & 349.43 & 384.81 & 376.37 & 369.80 \\
\hline No religion & 408.02 & 375.43 & 349.27 & 340.19 & 351.00 & 375.56 & 365.65 \\
\hline$p$ value & 0.059 & $0.015^{*}$ & 0.025* & 0.075 & 0.373 & $0.008^{*}$ & $0.012 *$ \\
\hline \multicolumn{8}{|l|}{ Sexual orientation } \\
\hline Heterosexual & 366.72 & $370.38^{+}$ & 362.80 & 363.67 & 362.61 & $366.07^{+}$ & 366.78 \\
\hline Homosexual & 358.89 & 391.79 & 390.11 & 357.25 & 306.46 & $458.04^{\ddagger}$ & 394.61 \\
\hline Bisexual & 322.19 & 323.38 & 379.38 & 306.42 & 370.46 & 346.23 & 343.23 \\
\hline Others & 313.88 & $271.12^{+}$ & 333.65 & 346.88 & 355.26 & $293.97^{+, \neq}$ & 301.35 \\
\hline$p$ value & 0.229 & $0.002 *$ & 0.668 & 0.724 & 0.781 & $0.014 *$ & 0.099 \\
\hline
\end{tabular}

*Statistical significance by Kruskal-Wallis $\mathrm{H}$ test $(\mathrm{p}<0.05)$.

+,*BBonferroni Post-hoc Test.

SS: sensory skills; AUT: autonomy; PPFA: past, present and future activities; SP: social participation; DD: death and dying; INT: intimacy; GQL: general quality of life.

Table 3 - General evaluation and comparison of the QoL of older adults with and with no suspicion of CMD - Ribeirão Preto, SP, Brazil, 2020.

\begin{tabular}{|c|c|c|c|c|c|}
\hline \multirow{3}{*}{ QoL facets } & \multicolumn{2}{|c|}{ CMD } & \multirow{3}{*}{ U } & \multirow{3}{*}{$p$ value } & \multirow{3}{*}{$\begin{array}{c}\text { General evaluation } \\
M_{d}(I R)\end{array}$} \\
\hline & No suspicion & Suspicion & & & \\
\hline & $M_{d}(I R)$ & $M_{d}(I R)$ & & & \\
\hline SS & $81.25(68.75-93.75)$ & $68.75(56.25-87.50)$ & 36859.500 & $<0.001 *$ & $81.25(68.75-93.75)$ \\
\hline AUT & $75.00(62.50-81.25)$ & $56.25(43.75-68.75)$ & 31551.000 & $<0.001 *$ & $68.75(56.25-75.00)$ \\
\hline PPFA & $75.00(62.50-81.25)$ & $56.25(43.75-68.75)$ & 26313.500 & $<0.001^{*}$ & $68.75(56.25-81.25)$ \\
\hline SP & $75.00(62.50-81.25)$ & $56.25(43.75-68.75)$ & 26646.500 & $<0.001 *$ & $68.75(56.25-75.00)$ \\
\hline DD & $75.00(56.25-87.50)$ & $59.37(37.50-75.00)$ & 36888.000 & $<0.001 *$ & $75.00(50.00-87.50)$ \\
\hline INT & $75.00(75.00-87.50)$ & $62.50(50.00-75.00)$ & 27219.500 & $<0.001 *$ & $75.00(62.50-81.25)$ \\
\hline GQL & $73.95(66.66-81.25)$ & $58.33(51.04-66.66)$ & 19738.000 & $<0.001 *$ & $69.79(59.89-79.16)$ \\
\hline
\end{tabular}

*Statistical significance by Mann-Whitney $U$ test $(p<0.05)$.

SS: sensory skills; AUT: autonomy; PPFA: past, present and future activities; SP: social participation; DD: death and dying; INT: intimacy; GQL: general quality of life. 
Table 4 - Correlation between CMD components and QoL facets - Ribeirão Preto, SP, Brazil, 2020.

\begin{tabular}{|c|c|c|c|c|c|c|c|}
\hline \multirow{3}{*}{ SRQ-20 } & \multicolumn{7}{|c|}{ WHOQOL-OId FACETS } \\
\hline & SS & AUT & PPFA & SP & DD & INT & GQoL \\
\hline & $\mathbf{r}$ & $\mathbf{r}$ & $\mathbf{r}$ & $\mathbf{r}$ & $\mathbf{r}$ & $\mathbf{r}$ & $\mathbf{r}$ \\
\hline Depressive-anxious mood & $-272^{*}$ & $-322^{*}$ & $-423^{*}$ & $-382 *$ & $-269 *$ & $-424^{*}$ & $-510^{*}$ \\
\hline Somatic symptoms & $-205^{*}$ & $-194^{*}$ & $-295^{*}$ & $-263 *$ & $-237^{*}$ & $-285^{*}$ & $-364^{*}$ \\
\hline Decrease in vital energy & $-332 *$ & $-367^{*}$ & $-393^{*}$ & $-389 *$ & $-214^{*}$ & $-377^{*}$ & $-501^{*}$ \\
\hline Depressive thoughts & $-211^{*}$ & $-387^{*}$ & $-486^{*}$ & $-460^{*}$ & $-178^{*}$ & $-441^{*}$ & $-520^{*}$ \\
\hline General SRQ-20 & $-279 *$ & $-342^{*}$ & $-434^{*}$ & $-413^{*}$ & $-276^{*}$ & $-425^{*}$ & $-528^{*}$ \\
\hline
\end{tabular}

*Statistical significance for Pearson correlation $(r)(p<0.001)$.

SS: sensory skills; AUT: autonomy; PPFA: past, present and future activities; SP: social participation; DD: death and dying; INT: intimacy; GQoL: general quality of life.

Table 5 - Final linear regression models for the independent (CMD) and the dependent (QoL) variable - Ribeirão Preto, SP, Brazil, 2020.

\begin{tabular}{|c|c|c|c|c|}
\hline & $\beta$ & $\mathrm{Cl} 95 \%$ & $\mathbf{p}$ & $\begin{array}{l}\text { Durbin- } \\
\text { Watson }\end{array}$ \\
\hline \multicolumn{5}{|c|}{ Sensory skills } \\
\hline $\begin{array}{l}\text { Depressive-anxious } \\
\text { mood }\end{array}$ & -1.533 & $-3.024--0.043$ & 0.044 & \multirow{2}{*}{2.026} \\
\hline \multirow[t]{2}{*}{$\begin{array}{l}\text { Decrease in vital } \\
\text { energy }\end{array}$} & -3.061 & $-4.265--1.857$ & $<0.001$ & \\
\hline & & Autonomy & & \multirow{3}{*}{1.791} \\
\hline $\begin{array}{l}\text { Decrease in vital } \\
\text { energy }\end{array}$ & -2.168 & $-3.355--0.981$ & $<0.001$ & \\
\hline \multirow[t]{2}{*}{ Depressive thoughts } & -4.937 & $-6.688--3.187$ & $<0.001$ & \\
\hline & \multicolumn{3}{|c|}{ Past, present and future activities } & \multirow{3}{*}{2.007} \\
\hline $\begin{array}{l}\text { Depressive-anxious } \\
\text { mood }\end{array}$ & -2.392 & $-3.755--1.028$ & 0.001 & \\
\hline \multirow[t]{2}{*}{ Depressive thoughts } & -6.798 & $-8.421--5.175$ & $<0.001$ & \\
\hline & \multicolumn{3}{|c|}{ Social participation } & \multirow{4}{*}{1.929} \\
\hline $\begin{array}{l}\text { Depressive-anxious } \\
\text { mood }\end{array}$ & -1.690 & $-3.168--0.211$ & 0.025 & \\
\hline $\begin{array}{l}\text { Decrease in vital } \\
\text { energy }\end{array}$ & -1.336 & $-2.530--0.142$ & 0.028 & \\
\hline \multirow[t]{2}{*}{ Depressive thoughts } & -6.639 & $-8.399--4.878$ & $<0.001$ & \\
\hline & \multicolumn{3}{|c|}{ Death and dying } & \multirow{3}{*}{1.970} \\
\hline $\begin{array}{l}\text { Depressive-anxious } \\
\text { mood }\end{array}$ & -2.492 & $-4.569--0.415$ & 0.019 & \\
\hline \multirow[t]{2}{*}{ Somatic symptoms } & -1.770 & $-3.394--0.146$ & 0.033 & \\
\hline & & Intimacy & & \multirow{3}{*}{1.950} \\
\hline $\begin{array}{l}\text { Depressive-anxious } \\
\text { mood }\end{array}$ & -2.760 & $-4.148--1.373$ & $<0.001$ & \\
\hline \multirow[t]{2}{*}{ Depressive thoughts } & -5.483 & $-7.135--3.832$ & $<0.001$ & \\
\hline & \multicolumn{3}{|c|}{$\begin{array}{l}\text { General quality of life } \\
\text { (WHOQOL-Old) }\end{array}$} & \multirow{5}{*}{1.960} \\
\hline $\begin{array}{l}\text { Depressive-anxious } \\
\text { mood }\end{array}$ & -2.050 & $-2.962--1.137$ & $<0.001$ & \\
\hline $\begin{array}{l}\text { Decrease in vital } \\
\text { energy }\end{array}$ & -1.460 & $-2.197--0.723$ & $<0.001$ & \\
\hline Depressive thoughts & -4.124 & $-5.211--3.038$ & $<0.001$ & \\
\hline $\begin{array}{l}\text { Common mental } \\
\text { disorder (SRQ-20) }\end{array}$ & -15.557 & $-17.387--13.728$ & $<0.001$ & \\
\hline
\end{tabular}

autonomy is a right guaranteed, even to older adults in conditions of dependence ${ }^{(20)}$ and in palliative care ${ }^{(19)}$.

Our results show that, regardless of the suspicion of CMD, older adults had better QoL in the sensory skills facets, corroborating a study ${ }^{(21)}$ and diverging from another ${ }^{(22)}$, in which a better perception of QoL in the intimacy facet was identified ${ }^{(22)}$. The sensory skills facet assesses the impacts of the loss of sensory functions (smell, taste, touch and hearing $)^{(18)}$ on the capacity for social interaction and on activities of daily living ${ }^{(23)}$.

Entering the field of QoL, this study showed that participants with no suspicion of CMD had better QoL in all facets when compared to those with suspicion, indicating that the presence of CMD is associated with reduced QoL in this age group. Thus, another Brazilian study ${ }^{(15)}$ identified that older adults with CMD had greater negative impacts on the physical and mental domains of QoL, assessed by instrument 12 - Item Short-Form Health Survey (SF-12).

Due to the natural aging process, age becomes a strong predictor for the development of psychological morbidities. Thus, with advancing age, individuals become more exposed to comorbidities, grief, widowhood, job loss, social isolation, economic difficulties and marital separations, which consequently facilitate the emergence of psychological problems ${ }^{(9,24)}$.

However, it is worth highlighting the abuses that are commonly observed against older adults, whose evidence estimates that 1 in 6 of them is a victim of some type of abusive aggression. Examples include verbal, physical, psychological, sexual and financial abuse, loss of respect, abandonment and neglect, which promote serious and lasting psychological consequences ${ }^{(24)}$.

Thus, even though they do not have a psychotic character, CMDs have a significant impact on public health, due to their undesirable effects in the family, individual and work environment, increasing the risk of exposure to psychological morbidities, with a consequent reduction in $\mathrm{QoL}^{(7)}$, corroborating our results. Another important finding was the fact that all CMD components showed negative and statistically significant correlations with all facets of QoL, and it was observed that depressive-anxious mood was the component that showed the most associations with almost all facets of QoL, with the exception of autonomy. These results are in agreement with Brazilian studies ${ }^{(3,8)}$ that identified a higher prevalence of the depressive-anxious mood component in the assessment of CMD among older adults. It is a dimension that assesses feelings of nervousness, worry, tension, fright, sadness and crying ${ }^{(25)}$. 
These results raise a concern that should be considered in the development of public health policies, as depressive-anxiety disorders are related to the increased chances of developing cardiovascular pathologies, physical and cognitive decline, systemic inflammation, oxidative stress, dysregulation in tone autonomous, metabolic syndrome, among other conditions sensitive to the health of older adults ${ }^{(26)}$.

Thus, considering the intensity of the negative repercussions of psychological problems for the health of older adults, the WHO reinforces that the mental health of this age group can be improved through the promotion of Active and Healthy Aging. Therefore, it is possible to start with the creation of living conditions and environments that ensure the well-being and enable a healthy life for individuals. However, it is worth emphasizing that the promotion of mental health in older adults depends on strategic actions that guarantee this population's accessibility to resources that meet their needs ${ }^{(24)}$.

Among these actions, the following stand out: adequate solidary housing policy; social support for older adults and their caregivers; social, health, community development and abuse prevention programs; training of health professionals; development of services and comfortable environments; prevention and management of age-associated chronic pathologies; among other strategic actions ${ }^{(24)}$. From this perspective, the Primary Health Care nurse plays a fundamental role in mental health actions, reinforcing the principles of the Psychiatric Reform, encouraging respect and the individuals' autonomy. This professional must act in a welcoming manner, with co-responsibility for holistic care ${ }^{(7)}$, considering the various factors that compromise the mental health and QoL of older adults.

Therefore, this study contributes to care practices, as it scientifically reveals the implications of the presence of CMD on the QoL of older adults, providing essential data for the planning and implementation of strategic actions that improve the QoL of this population, especially in view of the COVID-19 pandemic. This is because, although data collection was not designed for the specificity of the pandemic context, it occurred simultaneously with the initial advance of the disease in Brazil, a period in which there was still little information about the etiological agent and therapeutic measures.

So, this event must be considered as a possible factor that somehow influenced our results. This inference is justified based on some studies ${ }^{(12,27)}$, that have shown that older adults had significant impacts on their mental health during the COVID-19 pandemic. In addition, an investigation ${ }^{(27)}$ carried out with a total of 640 older adults living in Belgium showed a significant reduction in the level of activity, sleep quality and well-being during the pandemic context, with depression being a comorbidity that was strongly related to these outcomes.

It should be noted that most older adults do not have the necessary and sufficient resources to better deal with the stressors resulting from the pandemic, such as material, social and even cognitive resources ${ }^{(28)}$. In addition, the lack of interpersonal relationships due to social distancing increases psychological affections and the risk of depressive and anxiety symptoms, especially due to the suspension of religious activities, given that this is an important space for their socialization. Finally, fear and stress are also important factors that can contribute to the emergence and exacerbation of pre-existing mental disorders ${ }^{(12)}$. Therefore, given these evidence and considerations, it is considered that the pandemic caused by COVID-19 has significant implications for the mental health of older adults, which needs to be considered in health services and adapted to the pandemic context.

It is noteworthy that this study has important limitations that need to be considered. First, it concerns the non-probabilistic selection of participants, which can compromise the external validity of the results. Furthermore, it should be remembered that, due to the fact that data collection is online, the participation of older adults in the research may have been restricted to social strata with higher socioeconomic status, which may not represent most older adults users of the Unified Health System - Sistema Único de Saúde (SUS), despite being a universal and egalitarian system.

Thus, according to the National Household Sample Survey (NHSS) ${ }^{(29)}$, developed by the Brazilian Institute of Geography and Statistics - (IBGE), older adults represented the lowest percentage among other age groups that used the internet between 2017 and 2018, corresponding, respectively, to $31.2 \%$ and $38.7 \%$. This is a fact that reflects several factors, especially the level of education. Therefore, it is necessary to rethink public policies that act in basic education among older adults and that provide/encourage access to the internet for this public, as the literature already highlights the benefits that the use of the internet provides to older adults, as a prevention of depression and social isolation, maintenance of cognitive skills and stimulation of brain activities ${ }^{(30)}$.

Finally, as a last limitation, the fact that the sample consisted only of people who were married, in a stable relationship or with a regular partner may also have interfered with the results found here, given that other marital strata, such as widows, divorcees and single women were not part of the study, which requires caution when comparing our results with other investigations.

Despite these limitations, it is revealed that the results make contributions to the literature and to health actions. First, because we identified older adults with a high level of education, which differs from most studies carried out with the public in this age group ${ }^{(3,8-9)}$ and which may have influenced our results, especially in terms of better perception of QoL in the sensory skills facet. This finding was not expected because the aging process itself reflects losses and/or reduction in sensory functions. However, the socioeconomic benefits of individuals with high education may have favored access to services that ensured the preservation of these functions.

This is an important aspect, considering that, at the present time, it is a reality that is far from most Brazilian older adults. However, in the near future, the profile of older adults with a high level of education may become frequent, since the expansion of undergraduate and graduate courses in the 
country, which may influence the level of education of the future generation of older adults. Therefore, it is necessary to develop more research with this demographic profile, in order to obtain early information about this specificity.

Another important contribution is that, even in the face of the COVID-19 pandemic, older adults with no suspicion of CMD showed better QoL in all facets of assessment. This finding reinforces the need to increase mental health surveillance of the older adults population in order to protect it and reduce damage resulting from social isolation and the fatal repercussions of the pandemic daily reported by the television media.

\section{CONCLUSION}

The suspicion of CMD is negatively associated with QoL, that is, the increase in these disorders implied a reduction in the QoL of older adults. Furthermore, depressive-anxious mood was the component that was most associated with almost all facets of QoL, with the exception of the autonomy facet.

\section{RESUMO}

Objetivo: analisar a associação entre transtorno mental comum e qualidade de vida de pessoas idosas. Método: estudo seccional desenvolvido com 721 pessoas idosas brasileiras entre julho e outubro de 2020. Os participantes preencheram três instrumentos para avaliação dos dados biossociodemográficos, de saúde mental e qualidade de vida. Os dados foram analisados com os testes $U$ de $M a n n-$ Whitney, $H$ de Kruskal-Wallis, Qui-quadrado, correlação de Pearson e regressão linear multivariada, considerando um intervalo de confiança de $95 \%(p<0,05)$ para todas as análises. Resultados: dentre os quatro componentes que avaliam o transtorno mental comum, somente três permaneceram associados com coeficientes negativos, com a qualidade de vida geral dos participantes: humor depressivoansioso $(\beta=-2,050 ;$ [IC95\% = -2,962 - -1,137]; $\mathrm{p}<0,001)$, decréscimo de energia vital $(\beta=-1,460 ;[\mathrm{IC} 95 \%=-2,197--0,723] ; \mathrm{p}<0,001)$ e pensamentos depressivos $(\beta=-4,124 ;[\operatorname{IC} 95 \%=-5,211--3,038] ; p<0,001)$. Conclusão: a maioria dos componentes que avaliam o transtorno mental comum está negativamente associada à qualidade de vida, ou seja, o aumento desses transtornos implicou redução da qualidade de vida das pessoas idosas.

\section{DESCRITORES}

Saúde Pública; Saúde do Idoso; Saúde Mental; Transtornos Mentais; Envelhecimento; Qualidade de Vida.

\section{RESUMEN}

Objetivo: analizar la asociación entre los trastornos mentales comunes y la calidad de vida de los adultos mayores. Método: se trata de un estudio seccional que se llevó a cabo con 721 adultos mayores brasileños entre julio y octubre de 2020. Los participantes rellenaron tres instrumentos para evaluar los datos biosociodemográficos, de salud mental y de calidad de vida. Los datos se analizaron con la prueba U de Mann-Whitney, H de Kruskal-Wallis, Chi-cuadrado, correlación de Pearson y regresión lineal multivariada, considerando un intervalo de confianza del $95 \%$ ( $\mathrm{p}<0,05)$ para todos los análisis. Resultados: entre los cuatro componentes que evalúan el trastorno mental común, sólo tres permanecieron asociados a coeficientes negativos sobre la calidad de vida general de los participantes: humor depresivo-ansioso $(\beta=-2,050 ;$ [IC 95\%=-2,962--1,137]; $p<0,001)$, disminución de la energía vital $(\beta=-1,460 ;[$ IC 95\% $\%=-2,197-0,723] ; p<0,001)$ y pensamientos depresivos $(\beta=-4,124$; [IC 95\% =-5,211--3,038]; $\mathrm{p}<0,001)$. Conclusión: la mayoría de los componentes que evalúan el trastorno mental común están asociados negativamente a la calidad de vida; es decir, el aumento de estos trastornos implicó en una reducción de la calidad de vida de los adultos mayores.

\section{DESCRIPTORES}

Salud Pública; Salud del Anciano; Salud Mental; Trastornos Mentales; Envejecimiento; Calidad de Vida.

\section{REFERENCES}

1. United Nations. World Population Prospects: The 2015 Revision, Key Findings \& Advace Tables [Internet]. New York: United Nations; 2015 [cited 2021 Apr 22]. Available from: https://population.un.org/wpp/publications/files/key_findings_wpp_2015.pdf.

2. Veras RP, Oliveira M. Aging in Brazil: The building of a healthcare model. Ciênc Saúde Coletiva. 2018;23(6):1929-36. DOI: http://dx.doi. org/10.1590/1413-81232018236.04722018.

3. Silva PAS, Rocha SV, Santos LB, Santos CA, Amorim CR, Vilela ABA. Prevalência de transtornos mentais comuns e fatores associados entre idosos de um município do Brasil. Ciênc Saúde Coletiva. 2018;23(2):639-46. DOI: https://doi.org/10.1590/1413-81232018232.12852016.

4. Parreira BDM, Goulart BF, Haas VJ, Silva SR, Monteiro JCS, Gomes-Sponholz FA. Common mental disorders and associated factors: A study of women from a rural area. Rev Esc Enferm USP. 2017;51:e03225. DOI: http://dx.doi.org/10.1590/S1980-220X2016033103225.

5. McCallum SM, Batterham PJ, Calear AL, Sunderland M, Carragher N. Reductions in quality of life and increased economic burden associated with mental disorders in an Australian adult sample. Aust Heal Rev. 2019;43(6):652. DOI: https://doi.org/10.1071/AH16276.

6. Yimam K, Kebede Y, Azale T. Prevalence of Common Mental Disorders and Associated Factors among Adults in Kombolcha Town, Northeast Ethiopia. J Depress Anxiety 2014;S1:007. DOI: https://doi.org/10.4172/2167-1044.S1-007.

7. Fagundes IVO, Oliveira LPBA, Barros WCTS, Magalhães AG, Medeiros MRS, Pereira DO. Transtorno mental comum em idosos com doenças crônicas não transmissíveis na atenção primária à saúde. Ciência Cuid e Saúde [Internet]. 2020 [cited 2021 Feb 5];19:e50072. Available from: http://periodicos.uem.br/ojs/index.php/CiencCuidSaude/article/view/50072/751375149386.

8. Borim FSA, Barros MBA, Botega NJ. Transtorno mental comum na população idosa: Pesquisa de base populacional no Município de Campinas, São Paulo, Brasil. Cad Saúde Pública. 2013;29(7):1415-26. DOI: http://dx.doi.org/10.1590/S0102-311X2013000700015.

9. Vasconcelos-Rocha S, Almeida MMG, Araújo TM, Medeiros-Rodrigues WK, Barreto-Santos L, Virtuoso-Júnior JS. Prevalence of common mental disorders among elderly residents county in northeast of Brazil. Rev Salud Pública [Internet]. 2012 [cited 2021 Feb 5];14(4):620-9. Available from: http://www.scielo.org.co/scielo.php?script=sci_arttext\&pid=S0124-00642012000400007. 
10. Lima CKT, Carvalho PMM, Lima IAS, Nunes JAVO, Saraiva JS, Souza RI, et al. The emotional impact of coronavirus 2019-Ncov (new Coronavirus Disease). Psychiatry Res. 2020;287:e112915. DOI: https://doi.org/10.1016/j.psychres.2020.112915.

11. Pancani L, Marinucci M, Aureli N, Riva P. Forced social isolation and mental health: a study on 1006 Italians under COVID-19 quarantine. PsyArXiv [Preprint]. 2020: [22 p.]. DOI: https://doi.org/10.31234/osf.io/uacfj.

12. Fontes WHA, Gonçalves Júnior J, Vasconcelos CAC, Silva CGL, Gadelha MSV. Impacts of the SARS-CoV-2 Pandemic on the Mental Health of the Elderly. Front Psychiatry. 2020;11:841. DOI: https://doi.org/10.3389/fpsyt.2020.00841.

13. Mari JJ, Williams P. A validity study of a psychiatric screening questionnaire (SRQ-20) in primary care in the city of Sao Paulo. Br J Psychiatry. 1986;148(1):23-6. DOI: https://doi.org/10.1192/bjp.148.1.23.

14. Fleck MP, Chachamovich E, Trentini C. Development and validation of the Portuguese version of the WHOQOL-OLD module. Rev Saúde Pública. 2006;40(5):785-91. DOI: https://doi.org/10.1590/S0034-89102006000600007.

15. Martins AMEBL, Nascimento JE, Souza JGS, Sá MAB, Feres SBL, Soares BP, et al. The association between common mental disorders and subjective health conditions among the elderly. Ciênc saúde colet. 2016;21(11):3387-98. DOI: https://doi.org/10.1590/1413812320152111.07842015 .

16. Senicato C, Azevedo RCS, Barros MBA. Common mental disorders in adult women: Identifying the most vulnerable segments. Cienc Saúde Coletiva. 2018;23(8):2543-54. DOI: http://dx.doi.org/10.1590/1413-81232018238.13652016.

17. Sánchez-García S, García-Peña C, Ramírez-García E, Moreno-Tamayo K, Cantú-Quintanilla GR. Decreased autonomy in communitydwelling older adults. Clin Interv Aging. 2019;14:2041-53. DOI: https://doi.org/10.2147/CIA.S225479.

18. Jesus ITM, Diniz MAA, Lanzotti RB, Orlandi FS, Pavarin SCI, Zazzetta MS. Frailty and quality of elderly living in a context of social vulnerability. Texto Contexto - Enferm. 2018;27(4):e4300016. DOI: http://dx.doi.org/10.1590/0104-07072018004300016.

19. Gaspar RB, Silva MM, Zepeda KGM, Silva ÍR. Conditioning factors for nurses to defend the autonomy of the elderly on the terminality of life. Rev Bras Enferm. 2020;73(3):e20180857. DOI: https://doi.org/10.1590/0034-7167-2018-0857.

20. Gaspar RB, Silva MM, Zepeda KGM, Silva ÍR. Nurses defending the autonomy of the elderly at the end of life. Rev Bras Enferm. 2019;72(6):1639-45. DOI: https://doi.org/10.1590/0034-7167-2018-0768.

21. Almeida BL, Souza MEBF, Rocha FC, Fernandes TF, Evangelista CB, Ribeiro KSMA. Quality of life of elderly people who practice physical activities. Rev Fun Care Online. 2020;12:432-6. DOI: http://dx.doi.org/10.9789/2175-5361.rpcfo.v12.845.

22. Molina NPFM, Tavares DMS, Haas VJ, Rodrigues LR. Religiousity, spirituality and quality of life of elderly according to structural equation modeling. Texto Contexto - Enferm. 2020;29:e20180468. DOI: http://dx.doi.org/10.1590/1980-265X-TCE-2018-0468.

23. Simeão SFAP, Martins GAL, Gatti MAN, Conti MHS, Vitta A, Marta SN. Comparative study of quality of life of elderly nursing home residents and those attneding a day center. Ciênc Saúde Coletiva. 2018;23(11):3923-34. DOI: https://doi.org/10.1590/1413812320182311.21742016 .

24. World Health Organization. Mental health of older adults [Internet]. 2017 [cited 2021 Feb 5]. Available from: https://www.who.int/newsroom/fact-sheets/detail/mental-health-of-older-adults.

25. Oliveira EB, Zeitoune RCG, Gallasch CH, Pérez Júnior EF, Silva AV, Souza TC. Common mental disorders in nursing students of the professionalizing cycle. Rev Bras Enferm. 2020;73(1):e20180154. DOl: http://dx.doi.org/10.1590/0034-7167-2018-0154.

26. Van Milligen BAL, Verhoeven JE, Schmaal L, Van Velzen LS, Révész D, Black CN, et al. The impact of depression and anxiety treatment on biological aging and metabolic stress: Study protocol of the MOod treatment with antidepressants or running (MOTAR) study. BMC Psychiatry. 2019;19:425. DOI: https://doi.org/10.1186/s12888-019-2404-0.

27. Pue SD, Gillebert C, Dierckx E, Vanderhasselt MA, Raedt R, Bussche EV. The impact of the COVID-19 pandemic on wellbeing and cognitive functioning of older adults. Sci Rep. 2021;11:4636. DOI: https://doi.org/10.1038/s41598-021-84127-7.

28. Vahia IV, Jeste DV, Reynolds CF. Older Adults and the Mental Health Effects of COVID-19. JAMA. 2020;324(22):2253-54. DOI: https:// doi.org/10.1001/jama.2020.21753.

29. Instituto Brasileiro de Geografia e Estatística. PNAD Contínua TIC 2018: Internet chega a 79,1\% dos domicílios do país [internet]. 2020 [cited 2021 Jun 4]. Available from: https://agenciadenoticias.ibge.gov.br/agencia-sala-de-imprensa/2013-agencia-de-noticias/ releases/27515-pnad-continua-tic-2018-internet-chega-a-79-1-dos-domicilios-do-pais.

30. Miranda LM, Farias SF. As contribuições da internet para o idoso: uma revisão de literatura. Interface (Botucatu).2009;13(29):383-94. DOI: https://doi.org/10.1590/S1414-32832009000200011. 